\title{
Changes in quality during maturation of physalis fruit
}

\section{Mudanças na qualidade durante a maturação de frutos de fisális}

\author{
Polyana Barbosa da Silva ${ }^{1}$; Silvanda de Melo Silva ${ }^{2 *}$; Josilene Amaro da Silva ${ }^{3}$; \\ Rejane Maria Nunes Mendonça ${ }^{4}$; Walter Esfrain Pereira ${ }^{4}$
}

\begin{abstract}
The aim of this study was to evaluate the changes in quality of fruits of two species of physalis ( $P$. angulata and $P$. pubescens) harvested from family farmer orchards in different maturity stages, comparing with fully ripen fruits to those of the commercial species (P. peruviana) of similar maturity. The experiment was conducted in a completely randomized design, in five maturity stages for $P$. angulata and in four for $P$. pubescens. Data were submitted to variance analysis and means of the maturity stages compared by the Tukey test at $5 \%$ probability. For the comparison of fully ripen fruits of P. peruviana with the two species produced in different locations were used six replications and the means compared by Dunnett's test at $5 \%$ probability. The fruit diameter varied from 15.1 to $18.0 \mathrm{~mm}$ that classifies it as of caliber B. During maturation the color of the fruit evolved from green to totally yellow (P. angulata) and to yellow-brown with purplish features (P. pubescens). The soluble solids (SS) contents of the fruits of $P$. angulata were superior to those of $P$. pubescens and the commercial species. Comparing with commercial species, the SS/AT ratio was higher in locally produced fruits, indicating more palatable fruits. Fruits of $P$. angulata present favorable characteristics for fresh consumption, with potential for extensive cultivation and trade in family horticulture.
\end{abstract}

Key words: Caliber. Coloration. Physalis angulata. Physalis pubescens. Physalis peruviana.

\section{Resumo}

O objetivo deste estudo foi avaliar as mudanças na qualidade de frutos de duas espécies de fisális (P. angulata e P. pubescens) colhidas de hortas de agricultores familiares em diferentes estádios de maturação, comparando os frutos completamente maduros aos da espécie comercial (P. peruviana) de maturidade similar. $\mathrm{O}$ experimento foi conduzido em delineamento inteiramente casualizado, em cinco estádios de maturação para $P$. angulata e em quatro para $P$. pubescens. Os dados foram submetidos a análise de variância e as médias dos estádios de maturação comparadas pelo teste de Tukey a $5 \%$ de probabilidade. Na comparação dos frutos maduros da P. peruviana com os das espécies colhidas de diferentes localidades, foram utilizadas seis repetições, com as médias comparadas pelo teste de Dunnett, a $5 \%$ de probabilidade. O diâmetro do fruto variou de 15,1 a $18,0 \mathrm{~mm}$ que o classifica como de calibre B. Durante a maturação a coloração do fruto evoluiu do verde para completamente amarela (P. angulata) e para amarelo pardo com traços arroxeados (P. pubescens). O teor de sólidos solúveis (SS) de frutos de $P$. angulata foi superior aos da $P$. pubescens e da espécie comercial. Comparando com a espécie comercial, a relação SS/AT foi superior em frutos das espécies localmente produzidas, indicando frutos mais palatáveis. Assim, os frutos de $P$. angulata apresentam características favoráveis

1 M.e, Programa de Pós-Graduação em Ciência e Tecnologia de Alimentos, PPGCTA, Centro de Tecnologia, CT, Universidade Federal da Paraíba, UFPB, João Pessoa, PB, Brasil. E-mail: polyanabs@hotmail.com

2 Prof ${ }^{\mathrm{a}} \mathrm{Dr}^{\mathrm{a}}$, PPGCTA/CT/UFPB, João Pessoa, PB, Brasil. E-mail: silvasil@cca.ufpb.br

3 Dra ${ }^{\text {a }}$ PPGCTA/CT/UFPB, João Pessoa, PB, Brasil. E-mail: josileneamaro@yahoo.com.br

4 Profs. Drs., PPGA/CCA/UFPB, Areia, PB, Brasil. E-mail: rejaneufpb@yahoo.com.br; wep@cca.ufpb.br

* Author for correspondence

Received: Aug. 19, 2017 - Approved: Apr. 25, 2018 
para o consumo fresco, com potencial para amplo cultivo e comercialização na horticultura familiar.

Palavras-chave: Calibre. Coloração. Physalis angulata. Physalis peruviana. Physalis pubescens.

\section{Introduction}

Brazil presents one of the widest diversities of fruit species in the world due to its territorial extension and wide climatic variation. Its national fruit production still has great potential for expansion, considering the vast type of native and exotic fruits that have been little explored economically, however with great potential for family agriculture (TREVISANI et al., 2017). In this context, physalis is a fruit that

has aroused interest in some regions of the country (PEDÓ et al., 2013).

Physalis fruit and juice are both nutritious, containing particularly high levels of niacin, carotenoids and minerals (EL SHEIKHA et al., 2008). In addition, it contains considerable contents of vitamin $\mathrm{C}$, calcium and iron. Its fruits, roots, stems and leaves are used in traditional medicine, mainly as antipyretic, diuretic, antitumor, analgesic and anti-inflammatory treatments (CHIANG et al., 1992). Its juice is considered as being sedative and depurative, and is also used against rheumatism (WANG et al., 2009). This fruit can be eaten fresh or in salads, adding a bittersweet flavor to the dishes. The production of physalis derivatives is an interesting alternative for agroindustry. In some countries the fruit is processed to obtain jam, dairy drinks, yogurts, liqueurs, preserved fruits and ice creams (RUFATO et. al., 2008). Therefore, the cultivation of physalis can be an alternative for small and medium rural producers since the use of these products in the region is currently associated with extractive practices that puts the species at risk of reduction or even at the risk of extinction (ABREU et al., 2017).

Physalis is mainly cultivated in Colombia (HERRERA et al., 2012). However, countries in South America such as Ecuador, Peru, Chile and
Brazil have more recently increased the areas under cultivation (FISCHER et al., 2014). It was introduced as a commercial crop in Brazil in the State of São Paulo in 1999, and it later expanded to states such as Rio Grande do Sul and Minas Gerais (MOSCHINI et al., 2017; PEDÓ et al., 2013). Its good adaptation to the soil, the climatic conditions and the acceptance of the fruit were essential for the fruits' success in the country. Hence, Brazil is a potential producer of the fruit; yet, similar to any agricultural production chain, it depends on a series of factors involving efforts and investments from institutions (BETEMPS et al., 2014).

Physalis belong to the Solanaceae A. L. Jussieu family, genus Physalis L. In Brazil its fruit is known as canapu, camapum, or joá-de-capote, among other popular names, with spontaneous occurrence in the areas of Sertão and Mata in the Paraíba State, and it has been incorporated into small fruit plantations in family horticulture. This fruit is considered annual (MOSCHINI et al., 2017), and it can become more widely inserted in the regional agroindustrial chain in the short or medium term, considering that other locations already produce physalis-based products such as sweet preparations, marmalades, and jams (SILVA, 2013).

In Brazil, P. peruviana fruits are commercialized with great market potential, however, the naturally occurring species in the country $P$. angulata and $P$. pubescens, used in folk medicine and as part of the local diet, are still little explored in the horticultural context (BOTREL et al., 2017).

The medicinal potential of this genus is attributed to the presence of a group of substances derived from ergostane, called physalins, which has proven biological activity (NOGUEIRA et al., 2013), and in which the $P$. angulata L. species possesses great therapeutic potential (ABREU et al., 2017). 
Kusumaningtyas, Laily, Limandha (2015) reported phenolic compounds in $P$. angulata extracts that confer the species the potential of being a functional food, with effectiveness as an immunomodulator.

Studies on the phenology and characterization of the quality of $P$. Angulata and P. pubescens fruit are scarce, especially those focused on family farms in the Northeastern Brazil (SILVA, 2013). However, these studies are extremely important because they make it possible to establish market identity and quality standards for non-traditional fruits in the market, reducing the risks of failure with the introduction of these new crops (DANTAS et al., 2016).

In this sense, family farmers from Paraíba have started small cultivations of physalis. However, there are no studies describing the quality of fruits produced under these conditions. Therefore, the objective of this study was to evaluate the quality during maturation of two species of physalis fruits (P. angulata and P. pubescens), cultivated in six locations in the Paraíba State, and to compare the quality of the fruits classified as full mature with those of the commercial species (P. peruviana) at a similar maturity stage.

\section{Material and Methods}

The fruits of Physalis spp. were randomly harvested from family farmers of four localities in the state of Paraíba, Brazil, in the municipalities of São José da Lagoa Tapada (June), Sapé (July) and Santa Rita (Conjunto Eitel Santiago and Usina São João / August) 2015. The species of fruits harvested were classified as $P$. angulata $\mathrm{L}$ and $P$. pubescens L by the Herbarium Jaime Coelho de Moraes, DCB/CCA /UFPB. According to the Climatic Classification of Köppen-Geiger, the municipality of São José da Lagoa Tapada, located in Sertão Paraibano, presents a semi-arid climate of the BSh type, while Santa Rita and Sapé, both of which are located in the Mata Paraibana, present a tropical climate with dry season, being of type As.
The soils of the areas where the physalis samples were harvested are classified as typical Orthic CHROMIC LUVISOL (São José da Lagoa Tapada), Arenic Dystrophic RED-YELLOW ARGISOL (Sapé); Arenic Dystrophic RED ARGISOL (Santa Rita) (BRASIL, 1972), reclassified based on the 3rd edition of the Brazilian Soil Classification System (EMBRAPA, 2013).

The fruits of $P$. angulata were harvested from vegetable gardens located in the municipalities of Santa Rita (Eitel Santiago and the Usina São João), and in the municipalities of São José da Lagoa Tapada. The fruits of P. pubescens were harvested from the municipalities of Sapé and Santa Rita (Eitel Santiago).

In the laboratory, the calyx of fruits was removed. Fruits of $P$. angulata were classified in five maturity stages (totally green (TG), predominant green (PG), yellow pigmentation onset (YO), predominant yellow (PY), and totally yellow (TY), and P. pubescens in four (totally green (TG), predominant green (PG), yellow pigmentation onset with purple traits (YO), predominantly yellow with purple traits (PY). For the classification of the maturity stages was considered the evolution of the color of the fruit without the calyx.

In parallel, fruits of $P$. peruviana were purchased from a supermarket in the city of João Pessoa, whose origin was imports from Colombia according to the label, being marketed in carton packages of $100 \mathrm{~g}$ of fruits with the calyx. The color of fruits was bright orange, which was classified as full mature according to ICOTEC NTC 4580 (1999).

For fruits of the locally produced species, the maturity stages totally yellow (TY) and predominantly yellow with purple traits (PY) of $P$. angulata and P. pubescens, respectively, were considered completely mature when compared to P. peruviana. For the physical evaluations, 40 fruits of each cultivar of each maturity stage were used, each fruit being evaluated separately, considered as a replication. 
The physical evaluations were: Fresh mass, determined by the individual weighing of the fruits in semianalitical scale, expressed in grams (g); Length and diameter with the aid of a digital caliper, in millimeters $(\mathrm{mm})$; Objective color, measured through Minolta digital colorimeter and expressed in the parameters $L^{*}, a^{*}, b^{*}, \mathrm{C}$ and ${ }^{\circ} \mathrm{H}$, where: $L^{*}$ - corresponds to the brightness/luminosity; $a^{*}$ - defines the transition from the green color ($\left.a^{*}\right)$ to the red color $\left(+a^{*}\right)$ and $b^{*}$ - represents the transition from the blue color $\left(-b^{*}\right)$ to the yellow color $\left(+b^{*}\right)$, farther from the center $(=0)$, more saturated color; Chroma $\left(\mathrm{C}^{*}\right)$ (chromaticity or color intensity) and the Hue angle $\left({ }^{\circ} \mathrm{H}\right)$, where $0^{\circ}=$ red, $90^{\circ}=$ yellow, $180^{\circ}=$ green, $360^{\circ}=$ blue; and Firmness, determined in the intact fruits by digital bench Penetrometer (Soil Control - model PDBF - 200), expressed in Newton (N) (SANTOS et al., 2017).

For the physicochemical evaluations, four replications of about $200 \mathrm{~g}$ fruits were used for each maturity stage, and the fruits of each replication were homogenized in a blender and sifted to separate the seeds. The comparative evaluation of the quality of fruits at similar maturity of $P$. peruviana with the two locally produced species was performed in six replications of two packages of $100 \mathrm{~g}$.

The physicochemical evaluations were: Soluble Solids content (SS) - determined by digital refractometer at $20^{\circ} \mathrm{C}$, "Wya Abbe Refractometer", in \%; Titratable acidity (AT) - determined by titration to reach a slightly pink color, using $0.1 \mathrm{M} \mathrm{NaOH}$ solution and phenolphthalein (1\%) as indicator (RODRIGUES et al., 2018), expressed as (g citric acid.100g-1 pulp); SS/AT ratio was obtained by ratio between the contents of SS and AT (PALIYATH et al., 2008); Hydrogen ionic potential ( $\mathrm{pH})$ was determined through a digital potentiometer (RODRIGUES et al., 2018); Reducing sugars (RS) - determined with 3,5 dinitrosalicylic acid (DNS) according to Dantas et al. (2016), and expressed in $\left(\right.$ g.100 $\left.\mathrm{g}^{-1}\right)$; Total Soluble Sugars content (TSS)
- determined by the Anthrone method according adaptations of Dantas et al. (2016), expressed in (g. $\left.100 \mathrm{~g}^{-1}\right)$.

The experiment was carried on in a completely randomized design, considering maturity stages, corresponding to five stages of maturation for $P$. angulata and four stages for P. pubesnces, nested within each species and at harvest localities, based on Rodrigues et al. (2018). Forty fruits were used for the physical evaluations, consisting of 40 replications. For the physicochemical evaluations, it was used four replications of about $200 \mathrm{~g}$ of fruits each. Data were submitted to analysis of variance and the means were compared using the Tukey test at 5\% probability. The comparison of data of $P$. peruviana fruits with the two from locally produced species was performed in six replications and the means compared by Dunnett's test, at 5\% probability, using the software $\mathrm{SAS} \circledast 9.3$ (2012).

\section{Results and Discussion}

Table 1 shows the mean values of the physical characteristics for $P$. angulata and $P$. pubescens fruits at different maturity stages. The fruit's dimensions and fresh mass evolved throughout maturation for both cultivars, while firmness decreased with maturation. P.angulata and $P$. pubescens fruit reached the highest fresh mass at the predominantly yellow stage $(2.42 \mathrm{~g})$ and at the predominantly yellow with purple hues $(2.78 \mathrm{~g})$, respectively. In naturally occurring $P$. angulata fruits at the preripe stage, Oliveira et al. (2011) reported fresh mass varying from 1.50 to $7.06 \mathrm{~g}$ with a mean of 4.33 $\mathrm{g}$, which is much higher than those obtained herein for predominantly yellow fruits $(2.42 \mathrm{~g})$. This difference may be due to factors such as soil type, climate and occurrence of rainfall in the growing sites. Fresh mass and size, which consist of physical characteristics intrinsic to the species or cultivars, are used as attributes of quality for selecting and classifying products considering the consumer market (PALIYATH et al., 2008). 
Table 1. Fresh mass, length, diameter and firmness of $P$. angulata and P. pubescens fruits, harvested from producers in the state of Paraíba at maturity stages totally green (TG); predominantly green (PG); yellow pigmentation onset (YO); predominantly yellow (PY) and totally yellow (TY).

\begin{tabular}{lccccc}
\hline \multirow{2}{*}{\multicolumn{1}{c}{ Characteristics }} & TG & PG & Maturity Stages \\
\cline { 2 - 6 } & & P. angulata & YO & PY & TY \\
\hline Fresh mass (g) & $0.82 \mathrm{aD}$ & $1.27 \mathrm{bD}$ & $1.82 \mathrm{bC}$ & $2.42 \mathrm{aA}$ & $1.92 \mathrm{~B}$ \\
Length (mm) & $11.36 \mathrm{bC}$ & $14.22 \mathrm{aB}$ & $15.62 \mathrm{aA}$ & $15.81 \mathrm{aA}$ & $14.86 \mathrm{~B}$ \\
Diameter (mm) & $10.76 \mathrm{bD}$ & $13.56 \mathrm{aC}$ & $15.21 \mathrm{aA}$ & $15.32 \mathrm{aA}$ & $14.31 \mathrm{~B}$ \\
Firmness (N) & $8.05 \mathrm{bA}$ & $7.31 \mathrm{bA}$ & $5.16 \mathrm{bC}$ & $5.38 \mathrm{bC}$ & $6.62 \mathrm{~B}$ \\
\hline \multicolumn{5}{c}{$\boldsymbol{P .}$ pubencens } \\
\hline Fresh mass (g) & $1.53 \mathrm{aB}$ & $1.52 \mathrm{aB}$ & $2.21 \mathrm{aA}$ & $2.28 \mathrm{aA}$ & - \\
Length (mm) & $14.91 \mathrm{aB}$ & $14.34 \mathrm{aB}$ & $15.5 \mathrm{aA}$ & $15.72 \mathrm{aA}$ & - \\
Diameter (mm) & $13.61 \mathrm{aB}$ & $13.03 \mathrm{aB}$ & $15.24 \mathrm{aA}$ & $15.04 \mathrm{aA}$ & - \\
Firmness (N) & $15.99 \mathrm{aA}$ & $15.50 \mathrm{aA}$ & $10.11 \mathrm{aB}$ & $10.16 \mathrm{aB}$ & - \\
\hline
\end{tabular}

* Means followed by the same lowercase letter in the column (same characteristic, between species) and upper case in the row (maturity stages), do not differ by Tukey test at 5\% of probability; - Not available. $\mathrm{n}=8$ (maturity stages, of fruits from two localities).

P. pubescens fruit presented a mean length of 14.91 and $15.72 \mathrm{~mm}$ for totally green and predominantly yellow fruits, respectively, while the length of $P$. angulata and P. pubescens totally green, at the onset of yellow pigmentation and predominantly yellow fruits did not differ from one another (Table 1).

A minimum length of $13.8 \mathrm{~mm}$ of $P$. angulata fruits at the pre-ripe stage was reported by Oliveira et al. (2011), which is lower than the fruits of the same species from the present study at the predominantly green $(14.22 \mathrm{~mm})$, onset of yellow pigmentation (15.62 $\mathrm{mm}$ ) and predominantly yellow stages (15.81 $\mathrm{mm})$. On the other hand, these authors reported a maximum length of $24.0 \mathrm{~mm}$, which is higher than that found in this study. The diameter only differed for totally green fruits among the evaluated species (Table 1).

The Colombian Technical Standard (NTC 4580) (1999) establishes the caliber of $P$. peruviana fruits according to the diameter, which are: A, fruit with diameter $\leq 15.0 \mathrm{~mm}$; $\mathrm{B}$, between 15.1 and $18.0 \mathrm{~mm}$; C, between 18.1 and 20.0; D, between 20.1 and 22.0; and $\mathrm{E}$ with a diameter $\geq 22.1 \mathrm{~mm}$. Therefore, $P$. angulata and $P$. pubescens fruits produced in
Paraíba at the YO and PY stages are characterized as caliber B. Oliveira et al. (2011) reported a diameter of $18.6 \mathrm{~mm}$ at the pre-ripe stage for $P$. angulata fruit, which is higher than those obtained herein for $P$. angulata and $P$. pubescens fruits.

The firmness of $P$. angulata fruit decreased along maturation, increasing slightly in totally yellow fruits $(6.62 \mathrm{~N})$. For $P$. pubescens, the firmness also decreased with maturation, ranging from $15.99 \mathrm{~N}$ in the totally green stage to 10.66 $\mathrm{N}$ in the predominantly yellow stage (Table 1), characterizing firmer fruits.

Table 2 shows the evolution of $P$. angulata and $P$. pubescens fruit coloration throughout maturation. The $L^{*}$ increased as maturation advanced for $P$. angulata fruits, indicating their tendency in developing a lighter coloration. In turn, $L^{*}$ values for P. pubescens fruits did not differ during maturation.

Licodiedoff et al. (2013) reported luminosity of P. peruviana of 42.83 and 44.23 at the beginning of maturation for small and large fruits, respectively, which were similar to the values reported herein for totally green (42.64) and predominantly green (40.02) fruits of $P$. angulata and $P$. pubescens, 
respectively. At the end of maturation, these authors reported $L^{*}$ of 40.91 and 41.50 in small and large fruits, respectively, which were lower than for $P$. angulata totally yellow fruit (51.81) and similar to P. pubescens predominantly yellow fruit (40.15) reported herein.

Table 2. Lightness $\left(L^{*}\right)$, Color $a^{*}$, Color $b^{*}$, Chroma (C) and Hue Angle $\left({ }^{\circ} \mathrm{H}\right)$ of P. angulata and P. pubescens fruits, harvested from producers in the state of Paraíba at maturity stages totally green (TG); predominantly green (PG); yellow pigmentation onset (YO); predominantly yellow (PY) and totally yellow (TY).

\begin{tabular}{cccccc}
\hline \multirow{2}{*}{ Characteristics } & \multicolumn{5}{c}{ Maturity Stages } \\
\cline { 2 - 6 } & TG & PG & YO & PY & TY \\
\hline \multicolumn{5}{c}{ angulata } \\
$L^{*}$ & $42.64 \mathrm{aB}$ & $43.53 \mathrm{aB}$ & $46.23 \mathrm{aAB}$ & $49.53 \mathrm{aA}$ & $51.81 \mathrm{~A}$ \\
$a^{*}$ & $-7.24 \mathrm{aA}$ & $-3.53 \mathrm{aB}$ & $-2.53 \mathrm{bB}$ & $-0.86 \mathrm{aC}$ & 1.13 \\
$b^{*}$ & $44.38 \mathrm{aBC}$ & $41.76 \mathrm{aC}$ & $50.76 \mathrm{aA}$ & $46.24 \mathrm{aB}$ & $51 \mathrm{~A}$ \\
Chroma $(\mathrm{C})$ & $45.34 \mathrm{aB}$ & $42.15 \mathrm{aC}$ & $50.86 \mathrm{aA}$ & $46.29 \mathrm{aB}$ & $51.23 \mathrm{~A}$ \\
Hue Angle $\left({ }^{\circ} \mathbf{H}\right)$ & $98.85 \mathrm{aA}$ & $94.22 \mathrm{aB}$ & $93.15 \mathrm{bB}$ & $90.67 \mathrm{aBC}$ & $86.51 \mathrm{C}$ \\
\hline \multicolumn{5}{c}{$\boldsymbol{P .}$ pubencens } \\
$L^{*}$ & $40.02 \mathrm{aA}$ & $38.06 \mathrm{bA}$ & $39.97 \mathrm{bA}$ & $40.15 \mathrm{bA}$ & - \\
$a^{*}$ & $-8.46 \mathrm{bA}$ & $-2.32 \mathrm{aC}$ & $-4.3 \mathrm{aB}$ & $1.25 \mathrm{aC}$ & - \\
$b^{*}$ & $33.1 \mathrm{bA}$ & $28.83 \mathrm{bB}$ & $32.92 \mathrm{bA}$ & $28.02 \mathrm{bB}$ & - \\
Chroma $(\mathrm{C})$ & $34.19 \mathrm{bA}$ & $29.09 \mathrm{bB}$ & $34.11 \mathrm{bA}$ & $28.40 \mathrm{bB}$ & - \\
Hue Angle $\left({ }^{\circ} \mathbf{H}\right)$ & $104.32 \mathrm{aA}$ & $92.09 \mathrm{aB}$ & $97.33 \mathrm{aA}$ & $85.59 \mathrm{bC}$ & - \\
\hline
\end{tabular}

* Means followed by the same lowercase letter in the column (same characteristic, between specie) and upper case in the row (maturity stages), do not differ by Tukey test at $5 \%$ of probability; - Not available. $\mathrm{n}=8$ (maturity stages, of fruits from two localities).

The $a^{*}$ values increased throughout maturation, expressing the loss of green coloration for both $P$. angulata and $P$. pubescens fruits. Licodiedoff et al. (2013) reported $a^{*}$ values of 14.68 to 16.79 in $P$. peruviana fruit at the beginning of maturation, and of 17.88 and 18.67 at the end of maturation, being well above those found for $P$. angulata and $P$. pubescens fruits in this study. This difference explains the strong orange coloration of $P$. peruviana fruits in which the $a^{*}$ value tends to red, while the $P$. angulata and P. pubescens species at the end of maturation present a lighter yellow coloration.

The $b^{*}$ coloration for the $P$. angulata fruits varied from 44.38 in totally green fruits to 51 for those totally yellow. For P. pubescens, the $b^{*}$ coloration varied from 33.1 (totally green) to 28.02 (predominantly yellow) (Table 2 ). In $P$. peruviana fruit, Licodiedoff et al. (2013) reported $b^{*}$ of
19.71 and 20.23 at the beginning of maturation, and of 19.74 and 20.30 at the end of maturation; much lower than those found in $P$. angulata and $P$. pubescens fruit at all stages of maturation in this study. The highest $b^{*}$ values observed herein correspond to a fruit coloration tending to yellow, in which $P$. angulata had the highest values of $b^{*}$, representing more yellow fruits than those of $P$. pubescens. However, the coloration for fruits of both species studied evolved with maturation, so that the green tone was gradually replaced by the characteristic coloration. In this context, $P$. angulata fruit at full maturity had a light yellow color, which was clearly demonstrated by the $b^{*}(51.0)$, while P. pubescens fruits had a yellow color with purple tones/hues (28.2).

The chromaticity $(C)$ or color intensity in $P$. angulata fruit varied from 45.34 in totally green fruit 
to 51.23 in totally yellow ones. For $P$. pubescens fruit, the $C$ varied from 34.19 in totally green fruits to 28.40 in predominantly yellow ones. The Hue angle $\left(\mathrm{H}^{\circ}\right)$ decreased throughout maturation for $P$. angulata and P. pubescens fruits (Table 2). Values ranged from 98.85 in totally green fruits to 86.51 in totally yellow ones for $P$. angulata. Regarding P. pubescens, the $\mathrm{H}^{\circ}$ varied from 104.32 in totally green to 85.59 in totally yellow with purple tones fruits. Thus, the $\mathrm{H}^{\circ}$ parameter was able to clearly demonstrate the changes in coloration, decreasing with the maturation advance and reaching values close to $90^{\circ}$ at more mature stages (totally yellow and predominantly yellow), characterizing the yellow coloration. Lima et al. (2012) reported values of the Hue angle between 75.17 and $78.39^{\circ}$ in $P$. peruviana fruits whose sowing was carried out in September, and the seedlings transplanted in November; and between 73.12 and $78.23^{\circ}$ (coloration between orange to intense orange, characteristic of the species) for those planted in November and transplanted in January. These values are lower than those found in this study for P. angulata (86.51) and P. pubescens (85.59), which revealed fruits tending to the yellow color as maturation advanced.

Differences between all variables were observed by comparing the physical characteristics of more mature $P$. angulata and P. pubescens fruits with $P$. pervuviana fruits at similar maturity levels (Table 3). Regarding the fresh mass, fruits produced in Sapé (L6) had the lowest mass (1.65 g), while those from Etiel Santiago (L5) had the largest (2.91 g), although both were much lower than the commercial species $(4.37 \mathrm{~g})$. The length of the fruits ranged from 14.13 $\mathrm{mm}$ in Usina São João (L4) to $16.81 \mathrm{~mm}$ in Etiel Santiago (L5) (both in Santa Rita) for P. angulata and $P$. pubescens, respectively; smaller than those of the commercial species with a mean of $18.56 \mathrm{~mm}$. The diameter varied from $13.20 \mathrm{~mm}$ in fruits of São José da Lagoa Tapada (L2) and $16.78 \mathrm{~mm}$ in Etiel
Santiago (L5), while the commercial species had a higher value $(19.47 \mathrm{~mm})$. The fruit firmness of the commercial species was the lowest $(1.82 \mathrm{~N})$ when compared to the fruits of all the evaluated locations, in which the largest was $11.80 \mathrm{~N}$ (P. pubescens) in fruit from Sapé (L6), and the lowest was 6.15 in São José da Lagoa Tapada (L2) (P. angulata).

The mean $L^{*}$ value in fruits of the commercial species (P. peruviana) was 47.87 , being lower than that of fruits of $P$. angulata from São José da Lagoa Tapada (L2) (51.76) and Usina São João(L4) in Santa Rita (52.33), indicating that fruits locally produced have greater brightness. In turn, these values were higher than the $L^{*}$ from Etiel Santiago fruits (L5) in Santa Rita (44.93) and Sapé (L6) (35.38) for $P$. pubescens. These $L^{*}$ values reveal that there is a tendency for a lighter and bright coloration in $P$. angulata fruits, followed by commercial species $(P$. peruviana) and $P$. pubescens.

The $a^{*}$ values in fruits harvested from different locations were lower than those of the commercial species (19.29) whose fruits have orange coloration (characteristic of the $P$. peruviana species) with $a^{*}$ value tending more to red; this is different for $P$. angulata and P. pubescens species, in which the color of the fruits is lighter tending to yellow.

The $b^{*}$ values for the localities differed from the commercial species (P. peruviana) with 49.60, which were lower than fruits from São José da Lagoa Tapada (L2) (59.72) and higher than those from Usina São João (L4) in Santa Rita (33.44) for P. angulata, and in Etiel Santiago (L5) (35.01) and Sapé (L6 (21.03) for P. pubescens. Therefore, the fruit coloration from São José da Lagoa Tapada (L2) (P. angulata) tends to be more yellow than those of the commercial species, which in turn associated with a higher $a^{*}$ value present more orange fruits. Fruit from Etiel Santiago (L5) in Santa Rita and Sapé (L6) have a lighter yellow coloration, which is characteristic of these fruits. 
Table 3. Coloration of fruits of $P$. angulata and P. pubescens produced at different localities of Paraíba state and harvested at full (ripen) maturity stage and compared with the P. peruviana (commercial species) at similar maturity. Commercial (C); São José da Lagoa Tapada (L2); Santa Rita - Usina (L4) and (Santa Rita - Eitel Santiago (L5) and Sapé (L6)).

\begin{tabular}{cccccc}
\hline \multirow{2}{*}{ Characteristics } & \multicolumn{5}{c}{ Species } \\
\cline { 2 - 6 } & P. peruviana & \multicolumn{2}{c}{ P.angulata } & \multicolumn{2}{c}{ P.pubescens } \\
\cline { 2 - 5 } Fresh mass (g) & C & $1.70^{*}$ & $1.75^{*}$ & $2.91^{*}$ & $1.65^{*}$ \\
\cline { 2 - 5 } Length $(\mathrm{mm})$ & 18.56 & $14.20^{*}$ & $14.13^{*}$ & $16.81^{*}$ & $14.63^{*}$ \\
Diameter $(\mathrm{mm})$ & 19.47 & $13.20^{*}$ & $14.11^{*}$ & $16.78^{*}$ & $13.31^{*}$ \\
Firmness (N) & 1.82 & $6.15^{*}$ & $8.75^{*}$ & $8.52^{*}$ & $11.80^{*}$ \\
$L^{*}$ & 47.87 & $51.76^{*}$ & $52.33^{*}$ & $44.93^{*}$ & $35.38^{*}$ \\
$a^{*}$ & 19.29 & $-0.31^{*}$ & $6.15^{*}$ & $-2.18^{*}$ & $4.68^{*}$ \\
$b^{*}$ & 49.60 & $59.72^{*}$ & $33.44^{*}$ & $35.01^{*}$ & $21.03^{*}$ \\
Chroma $(\mathrm{C})$ & 53.33 & $59.77^{*}$ & $33.99^{*}$ & $35.11^{*}$ & $21.68^{*}$ \\
Hue Angle $\left({ }^{\circ} \mathbf{H}\right)$ & 68.78 & $88.16^{*}$ & $79.57^{*}$ & $93.75^{*}$ & $77.44^{*}$ \\
\hline
\end{tabular}

*Differ from fruits of $P$. peruviana at $5 \%$ of probability by the Dunnett test. Skin color at full (ripen) maturity stage: $P$. angulata totally yellow; P. pubescens - dark yellow with light purple stripes; P. peruviana - bright orange. $\mathrm{n}=6$.

The yellow color evolution from the reduced green color resulted from the maturation progress and it is due to the degradation of chlorophylls through chlorophyllases activation and the development of the characteristic coloration by the biosynthesis of pigments or unmasking of previously synthesized pigments (PALIYATH et al., 2008). For chromaticity (C), the variation among fruits from the harvesting localities was from 21.68 (Sapé (L6)) for $P$ pubescens, to 59.77 (São José da Lagoa Tapada (L2)) for P. angulata, and the commercial species showed 53.33, differing from those locally produced. Therefore, the chromaticity of commercial fruits (53.33) was lower than those produced in São José da Lagoa Tapada (L2) (59.77), and higher than those from Usina São João (L4) (33.99) and Etiel Santiago (L5) (both in Santa Rita) (35.11) and also in Sapé (L6) (21.68). In general, the color intensity was higher in fruits from São José da Lagoa Tapada (L2) with more fertile soils (Orthic CHROMIC LUVISOL), followed by the commercial species.

The $\mathrm{H}^{\circ}$ values of $P$. angulata and P. pubescens fruits from different localities ranged from 77.44 in Sapé (L6) to $93.75^{\circ}$ in Etiel Santiago (L5), corresponding to the yellow coloration, whose values were inferior to the corresponding strong orange coloration of the commercial species $\left(68.78^{\circ}\right)$. The fruits from São José da Lagoa Tapada (L2) and Etiel Santiago (L5) showed stronger yellow tones, followed by Usina São João (L4) and Sapé (L6). In commercial fruits, which are more orange, the $\mathrm{H}^{\circ}$ value tends to be more reddish. The ICOTEC NTC 4580 (1999) describes the changes of fruit coloration at different maturity stages in P. peruviana, in which coloration 0 (physiologically developed fruit in dark green color), coloration 1 (fruit having a light green color), coloration 2 (the green color remains close to the region of the calyx, while orange tones appear in the center of the fruit), coloration 3 (fruit has a light orange color with green tones up to the calyx zone), coloration 4 (fruit has a light orange color), coloration 5 (orange colored fruit) and coloration 6 (fruit has intense orange color).

The soluble solids (SS) content in P. angulata and $P$. pubescens fruits increased with maturation, but was higher in P. angulata (Table 4). The SS content in totally green $P$. angulata fruits was $7.26 \%$, while in totally yellow ones it was $14.21 \%$. For $P$. pubescens, the SS content in totally green fruits 
was $6.8 \%$, and the highest was in predominantly yellow fruits of $10.46 \%$. The SS content in fruits generally increases with the advance of maturation (PALIYATH et al., 2008), as was also observed in here in locally produced species of physalis fruits. According to the ICOTEC NTC 4580 (1999), for $P$. peruviana fruits the minimum SS content vary according to the coloration, from $9.4 \%$ for coloration 0 up to $15.1 \%$ for coloration 6 . The latter content was close to that found in P. angulata at the totally yellow stage (14.21\%) in this study.

Table 4. Hydrogen potential (pH), Soluble Solids (SS), Titratable acidity (AT), SS/TA Ratio, Reducing Sugars (RS) and Total Soluble Sugars (TSS) of fruits of $P$. angulata and $P$. pubescens, harvested at maturity stages totally green (TG); predominantly green (PG); yellow pigmentation onset (YO); predominantly yellow (PY) and totally yellow (TY).

\begin{tabular}{|c|c|c|c|c|c|}
\hline \multirow{2}{*}{ Characteristics } & \multicolumn{5}{|c|}{ Maturity Stages } \\
\hline & TG & $\mathrm{PG}$ & $\mathrm{YO}$ & PY & TY \\
\hline \multicolumn{6}{|c|}{ P. angulata } \\
\hline $\mathrm{pH}$ & $3.67 \mathrm{aC}$ & $3.97 \mathrm{aB}$ & $4.04 \mathrm{aB}$ & $4.36 \mathrm{aA}$ & $4.13 \mathrm{~A}$ \\
\hline SS $(\%)$ & $7.26 \mathrm{aC}$ & $9.92 \mathrm{aB}$ & $10.51 \mathrm{aB}$ & $11.86 \mathrm{aB}$ & $14.21 \mathrm{~A}$ \\
\hline TA (g citric acid. $100 \mathrm{~g}^{-1}$ pulp) & $1.63 \mathrm{aA}$ & $1.33 \mathrm{aB}$ & $0.99 \mathrm{bC}$ & $0.72 \mathrm{bC}$ & $0.80 \mathrm{C}$ \\
\hline SS/TA Ratio & $4.56 \mathrm{bC}$ & $9.96 \mathrm{bB}$ & $11.52 \mathrm{aB}$ & $16.71 \mathrm{aA}$ & $18.62 \mathrm{~A}$ \\
\hline $\operatorname{RS}\left(\mathrm{g} .100 \mathrm{~g}^{-1}\right)$ & $0.86 \mathrm{aA}$ & $0.63 \mathrm{aB}$ & $0.64 \mathrm{aB}$ & $0.64 \mathrm{aB}$ & $0.60 \mathrm{~B}$ \\
\hline TSS (g.100g $\left.\mathrm{g}^{-1}\right)$ & $2.33 \mathrm{aD}$ & $3.94 \mathrm{aC}$ & $7.48 \mathrm{aB}$ & $7.74 \mathrm{aB}$ & $8.3 \mathrm{~A}$ \\
\hline \multicolumn{6}{|c|}{ P. pubencens } \\
\hline $\mathrm{pH}$ & $3.75 \mathrm{aB}$ & $3.78 \mathrm{aB}$ & $3.65 \mathrm{bB}$ & $4.03 \mathrm{bA}$ & - \\
\hline SS $(\%)$ & $6.8 \mathrm{aC}$ & $7.7 \mathrm{bB}$ & $8.38 \mathrm{bB}$ & $10.46 \mathrm{bA}$ & - \\
\hline TA (g citric acid. $100 \mathrm{~g}^{-1}$ pulp) & $1.38 \mathrm{Ba}$ & $1.25 \mathrm{aC}$ & $2.04 \mathrm{aA}$ & $1.6 \mathrm{aB}$ & - \\
\hline SS/TA Ratio & $19.9 \mathrm{aA}$ & $18.39 \mathrm{aA}$ & $4.64 \mathrm{bC}$ & $9.79 \mathrm{bB}$ & - \\
\hline RS $\left(\mathrm{g} .100 \mathrm{~g}^{-1}\right)$ & $0.61 \mathrm{bA}$ & $0.49 \mathrm{aAB}$ & $0.52 \mathrm{aA}$ & $0.55 \mathrm{aA}$ & - \\
\hline TSS (g.100g $\left.\mathrm{g}^{-1}\right)$ & $1.33 \mathrm{bD}$ & $3.04 \mathrm{aC}$ & $4.47 \mathrm{bB}$ & $6.12 \mathrm{bA}$ & - \\
\hline
\end{tabular}

* Means followed by the same lowercase letter in the column (species) and upper case in the row (among maturation stages), do not differ by Tukey test at $5 \%$ of probability; - Not available. $\mathrm{n}=8$ (maturity stages, from fruits of two localities).

Oliveira et al. (2011) reported SS content of $12 \%$ in $P$. angulata fruits at the pre-ripe stage, close to the SS content of $P$. angulata fruits at the predominantly yellow stage $(11.86 \%)$ in this study. El Sheikha et al. (2008) reported SS content of $10.65 \%$ in $P$. pubescens, which were very close to those of predominantly yellow fruits $(10.46 \%)$ of $P$. pubescens reported herein.

Titratable acidity (TA) of $P$. angulata fruits decreased at more mature stages. For $P$. angulata, the highest TA content was in totally green fruits ( $1.63 \mathrm{~g}$ citric acid. $100 \mathrm{~g}^{-1}$ pulp), and the lowest was for totally yellow fruit $\left(0.8 \mathrm{~g}\right.$. citric acid. $100 \mathrm{~g}^{-1}$ pulp) (Table 4).
The highest TA for $P$. pubescens was for fruits at the onset of the yellow pigmentation (YO)

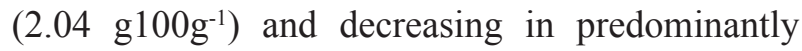

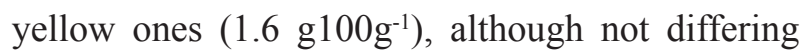
between totally green fruits $\left(1.38\right.$ g. $\left.100 \mathrm{~g}^{-1}\right)$ and predominantly yellow ones (1.6 g. citric acid. $100 \mathrm{~g}^{-1}$ pulp). This higher TA in $P$. pubescens than in $P$. angulata fruits may be due to genetic aspects. Oliveira et al. (2011) reported a TA of $0.68 \mathrm{~g}$ citric acid in $P$. angulata fruit at the pre-ripe stage, which is below those found in $P$. angulata and $P$. pubescens reported herein. El Sheikha et al. (2008) reported TA in fresh juice from P. pubescens of 1.43 $\mathrm{g}$, being lower than the fruit at the onset of yellow 
pigmentation (2.04) and in those predominantly yellow (1.6 g. citric acid. $100 \mathrm{~g}^{-1}$ of pulp). ICOTEC NTC 4580 (1999) establishes a maximum titratable acidity for $P$. peruviana fruits varying from 2.60 for coloration 0 (physiologically developed fruit of dark green color) to 1.68 (g citric acid. $100 \mathrm{~g}^{-1}$ ) pulp for coloration 6 (fruit with an intense orange color), the latter being higher than those determined from P. angulata and similar to P. pubescens fruits in the present study.

The SS/TA ratio increased throughout maturation in $P$. angulata fruits, while for $P$. pubescens it decreased up to the onset of yellow pigmentation (4.64) and increased in predominantly yellow fruits (9.79) (Table 4). The SS/TA differed between the stages of the two species, with $P$. angulata fruit presenting higher indexes at the end of maturation. Once TA was lower for $P$. angulata fruits that resulted in a higher SS/TA ratio, and therefore in sweeter fruits. The SS/TA ratio is used as indicator of the flavor, being more representative than the isolated determination of sugars and acidity (PALIYATH et al., 2008).

For P. peruviana fruit, according to the ICOTEC NTC 4580 (1999), the minimum maturation index SS/ TA ratio varies from 3.5 for color 0 (physiologically developed fruit with dark green color) to 9.0 for coloration 6 (fruit with an intense orange color). Therefore, $P$. angulata and $P$. pubescens fruits in this study showed a higher SS/TA ratio at the end of maturation than the minimum values established by this Technical Standard, being characterized as more palatable based on this concept.

Oliveira et al. (2011) reported a SS/TA ratio of 17.65 in $P$. angulata fruit at the pre-ripe stage, which was superior to that in predominantly yellow fruits (16.71) and lower than that reported herein for totally yellow $P$. angulata fruits (18.62). El Sheikha et al. (2008) reported a SS/TA of 7.59 in $P$. pubescens fruit juice, being lower than those from predominantly yellow fruits of this species (9.79) found herein.
As in most fruits, the $\mathrm{pH}$ of $P$. angulata increased as maturation advanced, not differing between predominantly yellow (4.36) and totally yellow fruits (4.13) (Table 4). The $\mathrm{pH}$ in P. pubescens fruits also increased with maturation, and totally green, predominantly green and at the onset of yellow pigmentation fruits differed from those which were predominantly yellow (4.03). El Sheikha et al. (2008) reported a $\mathrm{pH}$ of 3.5 for P. pubescens fruit juice, which was much lower than those found for the fruits of $P$. angulata and $P$. pubescens of the present study. Oliveira et al. (2011) reported a $\mathrm{pH}$ for $P$. angulata fruit at the pre-ripe stage of 4.11, being higher than those at the onset of yellow pigmentation (4.04), but close to totally yellow (4.13) P. angulata fruit evaluated herein.

In $P$. angulata fruit, the reducing sugar (RS) content decreased throughout maturation, not differing between predominantly green $(0.63$ g. $\left.100 \mathrm{~g}^{-1}\right)$ and totally yellow fruits $\left(0.60 \mathrm{~g} .100 \mathrm{~g}^{-1}\right)$ (Table 4). For P. pubescens fruits, the RS content was 0.61 in totally green fruit, and $0.55 \mathrm{~g} .100 \mathrm{~g}^{-1}$ in predominantly yellow ones, not differing from one another. Oliveira et al. (2011) found a RS content of 4.12 g. $100 \mathrm{~g}^{-1}$ in $P$. angulata fruit at the pre-ripe stage, well above those reported herein. El Sheikha et al. (2008) reported a RS content of 1.53 g. $100 \mathrm{~g}^{-1}$ for P. pubescens fruit juice, also higher than those found for $P$. angulata and $P$. pubescens fruits at all maturation stages in the present study. The differences in these results may be due to the evaluation methods used or due to soil and climatic characteristics of the production areas.

The total soluble sugars (TSS) content in $P$. angulata and $P$. pubescens fruits increased during maturation, reaching $8.73 ; 7.46$ g. $100 \mathrm{~g}^{-1}$ (totally yellow) and $6.12 ; 7.46$ g. $100 \mathrm{~g}^{-1}$ (predominantly yellow), respectively (Table 4). Oliveira et al. (2011) reported a TSS content of 6.45 g. $100 \mathrm{~g}^{-1}$ in $P$. angulata fruit at the pre-ripe stage, being lower than those in fruit at the onset of yellow pigmentation (7.48 g. $\left.100 \mathrm{~g}^{-1}\right)$ in P. angulata in this study. El Sheikha et al. (2008) reported a TSS content of 
2.35 for $P$. pubescens juice, which was lower than those found in predominantly green fruits (3.04), those at the onset of yellow pigmentation (4.47) and those predominantly yellow $\left(6.12 \mathrm{~g} .100 \mathrm{~g}^{-1}\right)$ for $P$. pubescens studied herein.

In this study, the TSS content was well above the RS levels, indicating the predominance of non-reducing sugars in the flavor composition. Also regarding TSS, the content was higher in $P$. angulata fruits, thus indicating that fruits of this species present superior quality characteristics to $P$. pubescens.
Physicochemical characteristics were compared based on the results of $P$. angulata and $P$. pubescens fruits in the more mature stage and of $P$. pervuviana at commercial maturity (Table 5). All evaluated characteristics differed between $P$. angulata and $P$. pubescens fruits when compared to $P$. pervuviana, except for the TSS content in fruits harvested at São José da Lagoa Tapada (L2) grown in a typical Orthic CHROMIC LUVISOL in the Sertão of Paraiba.

Table 5. Hydrogen potential (pH), Soluble Solids (SS), Titratable acidity (AT), SS/TA Ratio, Reducing Sugars (RS) and Total Soluble Sugars (TSS) of P. angulata and P. pubescens fruits produced at different localities of Paraíba state and harvested in the full (ripen) maturity stage and compared with the P. peruviana (commercial species). (Commercial (C); São José da Lagoa Tapada (L2); Santa Rita - Usina (L4); Santa Rita - Eitel Santiago (L5) and Sapé (L6).

\begin{tabular}{cccccc}
\hline \multirow{2}{*}{ Characteristics } & \multicolumn{5}{c}{ Localities } \\
\cline { 2 - 6 } & P. peruviana & \multicolumn{2}{c}{ P. angulata } & \multicolumn{2}{c}{ P. pubescens } \\
\cline { 2 - 6 } & C & L2 & L4 & L5 & L6 \\
\hline $\mathrm{pH}$ & 3.67 & $3.96^{*}$ & $4.60^{*}$ & $4.64^{*}$ & $3.41^{*}$ \\
$\mathrm{SS}(\%)$ & 12.92 & $13.50^{*}$ & $18.17^{*}$ & $10.50^{*}$ & $10.42^{*}$ \\
TA (g citric acid. $100 \mathrm{~g}^{-1}$ pulp) & 1.26 & $0.81^{*}$ & $0.66^{*}$ & $0.66^{*}$ & $2.54^{*}$ \\
SS/TA Ratio & 10.24 & $16.57^{*}$ & $27.50^{*}$ & $15.97^{*}$ & $3.60^{*}$ \\
RS $\left(\mathrm{g} .100 \mathrm{~g}^{-1}\right)$ & 5.43 & $0.62^{*}$ & $\mathrm{NA}$ & $0.67^{*}$ & $0.43^{*}$ \\
TSS $\left(\mathrm{g} .100 \mathrm{~g}^{-1}\right)$ & 9.90 & 9.40 & $\mathrm{NA}$ & $4.78^{*}$ & $7.46^{*}$ \\
\hline
\end{tabular}

* Means followed by an asterisk in the line differ from those for fruits of $P$. peruviana at $5 \%$ of probability by the Dunnett test. Skin color at full (ripen) maturity stage: $P$. angulata - totally yellow; $P$. pubescens - dark yellow with light purple stripes; $P$. peruviana - bright orange. $n=6 . \mathrm{NE}=$ Not available.

Sapé fruits (L6) presented a $\mathrm{pH}$ of 3.41, and those from Etiel Santiago (L5) had the highest $\mathrm{pH}$ at 4.64, while P. pervuviana had a $\mathrm{pH}$ of 3.67. The SS content varied between 10.42 to $18.17 \%$ in studied fruits, in which $P$. pervuviana (12.92\%) were superior to those from Etiel Santiago (L5) (10.50\%) and Sapé (L6) (10.42\%) (both P. pubescens), but inferior to those from São José da Lagoa Tapada (L2) (13.50\%) and Usina São João (L4) (18.17\%) (both $P$. angulata), confirming higher levels of SS for this latter species.

The TA in P. angulata and P. pubescens fruit from the localities was lower than that of $P$. pervuviana at
1.26, except for Sapé (L6) with 2.54 (g. citric acid. $100 \mathrm{~g}^{-1}$ pulp). The SS/TA ratio was 10.24 for fruits of this commercial species, which clearly differed from the localities with a lower value of 3.60 for Sapé (L6) due to a higher TA, and the highest of 27.50 for $P$. angulata from Usina São João (L4).

The RS content was lower $\left(0.43 \mathrm{~g} .100 \mathrm{~g}^{-1}\right)$ in fruit from Etiel Santiago (L5) and higher (0.67 g. $\left.100 \mathrm{~g}^{-1}\right)$ in those from Sapé (L6) (both $P$. pubescens), which were well below those of $P$. pervuviana (5.43 g. $\left.100 \mathrm{~g}^{-1}\right)$. TSS content of locally produced fruit also differed from the commercial species $(9.90$ g. $\left.100 \mathrm{~g}^{-1}\right)$, except for P. angulata from São José da 
Lagoa Tapada (L2) $\left(9.40 \mathrm{~g} .100 \mathrm{~g}^{-1}\right)$ that did not differ from $P$. pervuviana.

Regarding $P$. angulata fruit, those from Usina São João (L4) had the highest SS content, the lowest $\mathrm{TA}$, and therefore a higher SS/TA ratio compared to the $P$. pervuviana with the highest contents of RS and TSS. P. pubescens fruit harvested from Etiel Santiago (L5), located at the Mata Paraibana, had a lower acidity and higher SS/TA ratio than those of $P$. pervuviana; important aspects for their commercialization as fresh fruit or processing for producing jellies/marmalades, jams or juices.

The differences in fruit quality between $P$. peruviana and $P$. angulate, and $P$. pubescens may result from the genetic characteristics of each species, soil and climatic conditions and according to the cultivation.

\section{Conclusions}

For the fruits of locally produced physalis species, the diameter varied from 15.1 to $18.0 \mathrm{~mm}$, classifying those as of caliber B, according to the ICOTEC NTC 4580 (1999).

Fruits of from $P$. angulata have a higher SS content and higher SS/TA ratio than $P$. pubescens, and also higher than $P$. peruviana, indicating sweeter fruits. The TSS content of $P$. angulata fruits is similar to those of $P$. peruviana.

The low levels of reducing sugars present in $P$. angulata and $P$. pubescens with much higher TSS content indicate the major presence of non-reducing sugars in the composition of these fruits.

During maturation, the $P$. angulata coloration evolved from green to totally yellow, while those from $P$. pubescens evolved from green to dark yellow, with traces of purplish pigmentation on fully mature fruits.

The high SS/TA ratio in the $P$. angulata fruits produced in the Sertão and Mata areas in the state of Paraíba is a favorable factor for fresh consumption.
Consequently, $P$. angulata fruits produced in Paraíba state present favorable quality characteristics for fresh consumption, along with potential for cultivation in family farming and use in the food industry.

\section{Acknowledgments}

The authors thanks to the Brazilian National Counsel of Technological and Scientific Development (CNPq) for financial support (Grant \# 403847/2013-3) and to CAPES for the Scholarships.

\section{References}

ABREU, C. B.; SOUZA, M. O.; MIRANDA, F. M.; RODRIGUES, T. G. S.; DIAS, F. S. Growth and evaluation of phenolic compounds in Physalis angulata L. at two different periods in the Bahia Reconcavo, Brazilian Journal of Agricultural Science, Recife, v. 9, n. 10, p. 145-155, 2017.

BETEMPS, D. L.; FACHINELLO, J. C.; LIMA, C. S. M.; GALARÇA, S. P.; ANDREA DE ROSSI RUFATO, A. R. Época de semeadura, fenologia e crescimento de plantas de fisális no sul do Brasil. Revista Brasileira de Fruticultura, Jaboticabal, v. 36, n. 1, p. 179-185, 2014.

BOTREL, N.; MADEIRA, N. R.; MELO, R. A. C.; AMARO, G. B. Fisális - hortaliças não convencionais. Hortaliças tradicionais. Brasília: EMBRAPA HORTALIÇAS, 2017. Disponível em: <https:// www.infoteca. cnptia.embrapa.br/infoteca/handle/ doc/1071187?mode=full. $>$ Acesso em: $10 \mathrm{de}$ dez de 2017.

BRASIL. Ministério da Agricultura. Escritório de Pesquisas e Experimentação. Equipe de Pedologia e Fertilidade do Solo. I. Levantamento exploratório de reconhecimento dos solos do Estado da Paraíba. II. Interpretação para uso agrícola dos solos do Estado da Paraíba. Rio de Janeiro: SUDENE, 1972. 683 p. (Boletim técnico, 15. Série Pedologia, 8).

CHIANG, H. C.; JAW, S. M.; CHEN, C. F. Inhibitory effects of physalin B and physalin $\mathrm{F}$ on various human leukemia cells in vitro. Anticancer Research, Athens, v. 12, n. 4, p. 1155-62, 1992.

DANTAS, A. L.; SILVA, S. M.; DANTAS, R. L.; SCHUNEMANN, A. P. P. Desenvolvimento, fisiologia da maturação e indicadores do ponto de colheita de frutos da umbugueleira (Spondias sp,). Revista Brasileira de 
Fruticultura, Jaboticabal, v. 38, n. 1, p. 33-042, 2016.

EL SHEIKHA A.; ZAKI, M.; BAKR, A.; EL HABASHY M.; MONTET, D. Physico-chemical properties and biochemical composition of Physalis (Physalis pubescens L.) fruits. Global Science Books Ltd., London, v. 2, n.2, p. 124-130, 2008.

EMPRESA BRASILEIRA DE PESQUISA AGROPECUÁRIA - EMBRAPA Sistema brasileiro de classificação de solos. 3.ed. rev. e ampl. Brasília: Embrapa, 2013. 353 p.

FISCHER, G.; ALMANZA-MERCHÁN, P. J.; MIRANDA, D. Importancia y cultivo de la uchuva (Physalis peruviana L.). Revista Brasileira de Fruticultura, Jaboticabal, v. 36, n. 1, p. 1-15, 2014.

HERRERA, A. M. M.; FISCHER, G.; CHÁCON, M. I. S. Agronomical evaluation of cape gooseberries (Physalis peruviana L.) from central and northeastern Colombia. Agronomía Colombiana, Bogotá, v. 30, n. 1, p. 15-24, 2012.

INSTITUTO COLOMBIANO DE NORMAS TÉCNICAS Y CERTIFICACIÓN. Norma técnica colombiana Uchuva NTC 4580. Bogotá: ICOTEC, 1999. $17 \mathrm{p}$.

KUSUMANINGTYAS, R. W.; LAILY, N.; LIMANDHA, P. Potential of Ciplukan (Physalis angulata L.) as Source of Functional Ingredient. Procedia Chemistry, Amsterdam, v. 14, n. 1, p. 367-372, 2015.

LIMA, C. S.; MA.; GALARÇA, S. P.; BETEMPS, D. L.; RUFATO, A. R.; RUFATO, L. Avaliação física, química e fitoquímica de frutos de physalis, ao longo do período de colheita. Revista Brasileira de Fruticultura, Jaboticabal, v. 34, n. 4, p. 1004-1012, 2012.

LICODIEDOFF, S.; KOSLOWSKI, L. A. D.; RIBANI, R. H. Flavonols and antioxidant activity of Physalis peruviana L. fruit at two maturity stages. Acta Scientiarum Technology, Maringá, v. 35, n. 2, p. 393-399, abr./ jun. 2013.

MOSCHINI, B. P.; COELHO, V. A. T; PECHE, P. M.; SOUZA, F. B. M.; COUTINHO, G.; BARBOSA, C. M. A.; FREIRE, A. I. Crescimento e diagnose de deficiências nutricionais em Physalis peruviana L. Revista Agropecuária Técnica, Areia, v. 38, n. 4, p. 169176, 2017.

NOGUEIRA, R. C.; ROCKENBACH, I. I.; CATANEO, C.; GONZAGA, L. V.; CHAVES, E. S. Genotoxicity and antileishmanial activity evaluation of Physalis angulata concentrated ethanolic extract. Environmental Toxicology and Pharmacology, Iowa City, v. 36, n. 3, p. 1304-1311, 2013.
OLIVEIRA, J. A. R.; MARTINS, L. H. S.; VASCONCELOS, M. A. M.; PENA, R. S.; CARVALHO, A. V. Caracterização física, físico-química e potencial tecnológico de frutos de camapu (Physalis angulata L.). Revista Brasileira de Tecnologia Agroindustrial, Ponta Grossa, v. 5, n. 2, p. 573-583, 2011

PALIYATH, G. MURR, D. P.; HANDA, A. K.; LURIE, S. Postharvest biology and technology of fruit, vegetables, and flowers. Ames: Wiley-Blackwell, 2008. 497 p.

PEDÓ, T.; AUMONDE, T. Z.; LOPES, N. F.; VILLELA, F. A.; MAUCH, C. R. Growth analisys and assimilate partitioning in physalis plants under leaf fertilization intervals. Semina: Ciências Agrárias, Londrina, v. 34, n. 5, p. 2247-2256, 2013.

RODRIGUES, A. A. M.; SILVA, S. M.; DANTAS, A. L.; SILVA, A. F.; SANTOS, L. S.; MOREIRA, D. N. Physiology and postharvest conservation of 'Paluma' guava under coatings using Jack fruit seed-based starch. Revista Brasileira de Fruticultura, Jaboticabal, v. 40, n. 2, (e-352) p. 33-40, 2018.

RUFATO, L.; RUFATO, G.; RUFATO, A. R.; SCHLEMPER, C.; LIMA, C. S. M.; KRETZSCHMAR, A. A. Aspéctos técnicos da cultura da Physalis. LAGES: CAV/UDESC; Pelotas: UFPel, 2008.100 p.

SANTOS, L. S.; SILVA, S. M.; DANTAS, A. L.; SILVA, A. F.; RODRIGUES, A. A. M.; SILVA, G. C.; NASCIMENTO, L. C.; MENDONÇA, R. M. N. Quality of 'Isabel' grape treated pre-harvest with $\mathrm{CaCl}_{2}$ and citrus biomass-based elicitor. Semina: Ciências Agrárias, Londrina, v. 38, n. 5, p. 2945-2955, 2017.

SAS Institute. Base SAS 9.3 Procedures Guide: Statistical Procedures, SAS Institute Inc. Cary, North Carolina. 2012.

SILVA, P. B. Qualidade, compostos bioativos e atividade antioxidante de frutos de Physalis sp. 2013. Dissertação (Mestrado em Ciência e Tecnologia de Alimentos) Universidade Federal da Paraíba, João Pessoa.

TREVISANI, N.; MELO, R. C.; COLLI, M. P.; COIMBRA, J. L. M.; GUIDOLIN, A. F. Associations between traits in fisális: a tool for indirect selection of superior plants. Revista Brasileira de Fruticultura, Jaboticabal, v. 39, n. 4, (e-106) p. 1-7, 2017.

WANG, P.; ZHANG, Y.; LI, S.; LI, D. Effect on the immunological competence of Physalis pubescens L. in mice. Food and Agricultural Immunology, v. 20, n. 2, p. 165-172, 2009. 
